\title{
ОБҐРУНТУВАННЯ ЦІЛЬОВОГО ПРОФІЛЮ ЯКОСТІ ДЛЯ РОЗРОБКИ КОМБІНОВАНИХ ОЧНИХ КРАПЕЛЬ ДЛЯ ТЕРАПІЇ ГЛАУКОМИ
}

\author{
() О. М. Якубчук, О. Г. Фетісова, О. В. Доровський, Л. М. Андрюкова \\ Національний фрармацевтичний університет, Харків
}

\begin{abstract}
Резюме: в статті обґрунтовано розробку комбінованих очних крапель антиглаукомної дії. Обґрунтування очікуваного набору показників якості ЛП, який в ідеалі буде досягнутий для виконання передбачуваної срункції, проведено з застосуванням як наукових підходів до огляду і оцінки матеріалів різних інфрормаційних джерел щодо комбінованої терапії глаукоми препаратами різноспрямованої дії, так і наявних наукових знань щодо лікарської форми очні краплі.
\end{abstract}

Ключеві слова: комбіновані очні краплі, глаукома, цільовий профіль якості, показники якості

Вступ. Належним чином проведена фрармацевтична розробка (ФР) $€$ важливою умовою забезпечення якості, безпечності та ефективності лП протягом усього його життєвого циклу. Існують різні підходи до проведення ФР, наприклад такі, що наведені в [1], а саме - емпіричний, систематизований («Якість шляхом розробки») або комбінований з застосуванням обох перелічених підходів. Ключовим елементом фрармацевтичної розробки ЛП, незалежно від того, який підхід застосований, є визначення цільового профрілю якості - очікуваного набору показників якості ЛП, який в ідеалі буде досягнутий для забезпечення необхідної якості ЛП. Цільовий профріль якості фрормує основу для планування розробки ЛП, для глибокого розуміння препарату, а також процесу його виробництва. Він включає такі аспекти, як передбачуване застосування у клінічних умовах, безпечність та ефрективність з урахуванням шляху введення, лікарської фооми, біодоступності, сили дії, критеріїв якості та стабільності. Мета даної роботи полягала у визначенні цільового профілю якості для планування розробки комбінованих очних крапель антиглаукомної дії на основі тимололу малеату та таурину.

Методи дослідження. В роботі використано сучасні наукові методи: пошук, ретроспективний огляд та аналіз наукової літератури щодо даних, необхідних для визначення цільового профрілю якості для розробки комбінованих очних крапель на основі тимололу малеату та таурину згідно з [1]. У дослідженнях використовували матеріали Державного реєстру лікарських засобів України [2], вітчизняних та закордонних довідників лікарських засобів, фрармакопеї провідних країн світу [3-5], статті наукових фрахових видань [6-17, 23-27, 29, 32-33] та патентну літературу [18, 28, 30-31]. Об'єктами дослідження були активні фрармацевтичні інгредієнти тимололу малеат і таурин та лікарські препарати (лП) у формі очних крапель на основі тимололу малеату та таурину.

Результати й обговорення. Обґрунтування цільового профілю якості комбінованих очних крапель антиглаукомної дії проведено для усіх аспектів, що рекомендовані Настановою СТ-Н МОЗУ 42-3.0:2011. Лікарські засоби. Фармацевтична розробка (ICH Q8) [1] $з$ врахуванням особливостей лікарської форми, i викладені послідовно, а саме, передбачуване застосування у клінічних умовах, шлях введення, лікарська форма, системи доставки; сила дії дози; система контейнер/закупорювальний засіб; критерії якості лікарського препарату, відповідні призначеній для розміщення на ринку продукції.

Передбачуване застосування у клінічних умовах, шлях введення, лікарська фрорма, системи доставки.

Пріоритетом сучасної гіпотензивної терапії у пацієнтів являється комбінована терапія [6-8]. Комбінації речовин різноспрямованої дії (зниження утворення водянистої вологи і посилення її відтоку) призводять до більш вираженого зниження ВОТ порівняно з монотерапією кожним препаратом окремо [6-7]. Для пацієнта найбільш ефективною та зручною $є$ терапія за допомогою комбінованих препаратів, для яких відсутній ризик додаткового подразнення ока та вимивання попереднього препарату кожною наступною інстиляцією, що призводить до істотного зниження еорективності терапії [9].

Найрозповсюдженим представником як з монопрепаратів першого вибору, так і комбінованих препаратів, до сьогодні залишається адренергічний засіб тимололу малеат, що належить до групи неселективних $\beta$-адреноблокаторів [6-10]. Тимолол, блокуючи $\beta 1$ і $\beta 2$-адренорецептори циліарного тіла, знижує рівень ВОТ (як нормального, так і підвищеного) за рахунок зменшення утворення водянистої вологи в циліарному епітелії за відсутності позитивного впливу на їі

ISSN 2312-0967. Pharmaceutical review. 2015. № 4 
Фармацевтична технологія, біофармація, гомеопатія Pharmaceutical technology, biopharmacy, homeopathy

відтік [2-6]. При місцевому застосуванні ЛР швидко проникає через рогівку. Дія проявляється через 20 хв після інстиляції в кон'юнктивальну порожнину, $\mathrm{C}_{\max } \mathrm{y}$ водянистій волозі ока досягається через 1-2 год. У незначній кількості потрапляє в системний кровотік шляхом абсорбції через судини кон'юнктиви, слизової носа і слізного тракту. Тривалість гіпотензивної дії зберігається до 12-24 год після останньої інстиляції.

Тимолол у фрормі хемігідрата малорозчинний у воді, тому в офртальмологічних препаратах використовується його сольова фрорма з малеїновою кислотою у вигляді малеату.

В офтальмології тимолол застосовується у формі очних крапель (Арутимол ${ }^{\circledR}$, Кузімолол ${ }^{\circledR}$, Офртимол, Офртан $^{\circledR}$ Тимолол та інш.) та очного гелю (Ніолол) [2-5].

Дані про те, що речовини, які стабілізують мембранотропні ділянки адренергічних рецепторів, можуть змінювати фрармакологічну активність адренергічних засобів, 3'явилися у 80-х роках минулого століття [11-12]. Однією з таких речовин $€$ таурин (12-аміноетансульфонова кислота), який має широкий спектр біологічних властивостей: є стабілізатором клітинних мембран, антиоксидантом, нормалізує обмінні процеси на клітинному рівні, нормалізує процеси клітинної осморегуляції в умовах гіпо- або гіпертонічного середовища, збільшує оксигенацію водянистої вологи утилізацію кисню тканинами ока [13-14]. Проведений ряд досліджень показав посилення гіпотензивної дії при комбінованому застосуванні тимололу малеату 3 таурином за рахунок зниження продукування і збільшення відтоку водянистої вологи, що пояснюється фрармакологічним синергізмом дії обох препаратів на ендотелій шлемівого каналу і трабекули, який забезпечує збільшення відтоку водянистої вологи через дренажну систему ока [15-17]. За результатами досліджень вказано на перспективність і доцільність створення комбінованої очної лікарської фрорми на основі цих речовин. Цей ефект знайшов безпосереднє застосування в клінічній практиці: в інструкції для медичного застосування тауфрону надано рекомендацію щодо його застосування разом з тимололом для лікування відкритовугільної глаукоми [2-5]. Такі властивості таурину, як нормалізації фрункцій клітинних мембран, оптимізації енергетичних і обмінних процесів, підтриманню сталості електролітного складу цитоплазми клітин, гальмуванню синаптичної передачі (нейромедіаторна роль) є особливо важливими з точки зору побічних дій від постійного використання гіпотензивних ЛП, які проявляються аномаліями прекорнеальної плівки, хронічним дискомфортом та пошкодженнями клітин епітелію рогівки.

Також $є$ дані про ефрективність ЛП з таурином як засобу з протизапальною, репаративною дією, які свідчать про виражену репаративну та терапевтичну дію гелю для очей таурину 4 \% «Таугель» при лікуванні дистрофрічних уражень сітківки оболонки ока [18].
В офтальмології таурин застосовується у фрормі очних крапель (Тауфрорин «ОЗ» ТОВ «Дослідний завод «ГНЦЛС», Україна [2-3]; Тауфон-ЛЭНС, ООО «ЛЭНС-Фарм», Росія [4-5]; Bestoxol (Eye Drops), World Medicine Ophthalmics, Великобританія [19]; Taurine Eye Drops, Hangzhou East Pharmaceutical Co., Ltd., Китай [20]; Taurine Eye Drops, Hubei Kangzheng Pharmaceutical Co., Ltd., Китай [21]; Taurine Eye Drops 0,4g/8ml, AdvaCarePharma, Китай [22].

Результати аналізу літературних даних щодо глаукоми свідчать про наявність побічних ефектів від постійного використання гіпотензивних очних крапель, що проявляється дискомфортом та сухостою ока, порушенням стану слізної плівки та сльозопродукції, подразненням та порушенням епітелію рогівки та кон'юнктиви [23]. Очні краплі тимололу не $€$ виключенням 3 цієї проблеми, що доведено різноманітними клінічними дослідженнями. Авторами [24] відзначено найбільше прогресування ССО при застосуванні пацієнтами $\beta$-блокаторів і комбінації $\beta$-блокаторів 3 холіноміметиками (тимолол і пілокарпін).

Раціональний вибір та наступне ведення до композиції очних крапель речовин різної хімічної природи, які за різними механізмами впливають на стабільність слізної плівки та проявляють репаративну і захисну дію на клітини рогівки та кон'юнктиви, може допомогти вирішити одразу дві задачі: по-перше, це покращення біодоступності та пролонгація дії ЛР і по-друге -профрілактика та лікування побічних ефектів від постійного використання гіпотензивних очних крапель.

У літературі наведено багато інформації, присвяченої питанню біодоступності та пролонгації дії різних ЛР, які використовують в офтальмології, за допомогою тих чи інших ДР. Існують повідомлення про дослідження в цьому напрямку як 3 тимололом, так і 3 таурином.

Дослідженнями встановлено поліпшення біодоступності тимололу при використанні офтальмологічних розчинів з ПВС [25-26], поліакриловою кислотою [26], ГЕЦ [27], ГПЦ [25], гіалуроновою кислотою [25], ПВП [11], альгіновою кислотою [28], каприновою кислотою [29]. Залежно від використання в'язкоутворюючого компоненту в різному ступені спостерігалося зменшення системного всмоктування тимололу, що пояснювалося різною хімічною природою ДР [23]. Для полегшення симптомів сухого ока у лП тимололу також пропонують додавати ГПМЦ [30]. Результати богаточисельних досліджень втілились у готові препарати тимололу для використання в офтальмології такі, як Арутимол ${ }^{\circledR}$, Chauvin ankerpharm $\mathrm{GmbH}$, Ніолол ${ }^{\circledR}$, Novartis Pharma AG, які покращені за рахунок введення ДР.

Незважаючи на відсутність готових препаратів таурину з різними високомолекулярними речовинами, дослідження щодо поліпшення впливу на симптоми

ISSN 2312-0967. Фармацевтичний часопис. 2015. № 4 
подразнення поверхні ока та біодоступності лП проводились. Так, за результатами фрармакологічних досліджень впливу комбінованого розчину ксантанової камеді та таурину на відновлення клітин епітелію рогівки порівняно з окремими розчинами цих же речовин встановлено поліпшену захисну дію комбінації речовин на епітелій рогівки [31]. В роботі [18] збільшення часу перебування ЛР в кон'юнктивальному мішку і, таким чином, подовження тривалості її дії, а також зменшення кратності добового прийому досягається за допомогою підвищення в'язкості дисперсного середовища шляхом включення таурину в гель на основі карбополу.

Вищеперелічені знання стали підставою проведення досліджень з розробки комбінованого лП антиглаукомної дії на основі тимололу малеату, який знижує утворення водянистої вологи, та таурину, який забезпечує збільшення відтоку водянистої вологи, а також включення в комбінацію речовин, які впливають на стабільність слізної плівки та проявляють захисну і репаративну дію на клітини рогівки та кон'юнктиви i, таким чином, запобігають появі побічних ефектів від постійного використання гіпотензивних очних крапель. Враховуючи, що очні краплі на даний час $€$ однією 3 найрозповсюджених і зручних лікарських фрорм в застосуванні серед усіх офтальмологічних лікарських засобів, для комбінованого лП на основі тимололу малеату та таурину обрана лікарська фрорма очні краплі.
Фармацевтична технологія, біофармація, гомеопатія Pharmaceutical technology, biopharmacy, homeopathy

Сили дії дози.

Вибрані нами для розробки очних крапель лР є відомими і застосовуються в складі очних крапель (монопрепарати), їх терапевтичні концентрації наведені в довідковій літературі, тому для дослідження обрано концентрації 0,34 \% для тимололу малеату та 4 \% -для таурину. [2-5].

Система контейнер/закупорювальний засіб.

В якості первинного пакування існуючих на ринку готових монопрепаратів тимололу і тауфона у формі очних крапель використовуються фрлакони з поліетилену або скла. Поліетиленові фрлакони можуть бути виготовлені способом Blow-Fill-Seal packaging system або бути збірними контейнерами, що складаються 3 фрлакону, кришки-крапельниці та ковпачка. Флакони зі скла укупорюють гумовими пробками та обтискують ковпачками алюмінієвими. Місткість фрлакону складає від 1 мл до 10 мл. Приклади первинного пакування очних крапель тимололу і таурину (таусон) вітчизняних та зарубіжних фрармацевтичних підприємств наведено у таблиці 1 [2-5].

Планування вибору системи контейнер/закупорювальний засіб здійснено 3 врахуванням, по-перше, досвіду застосування первинного пакування існуючих на ринку готових монопрепаратів тимололу і тауфону, по-друге, наявних можливостей промислового виробництва очних крапель в Україні в різних видах первинного пакування. Враховуючи кількість призначень інстиляцій препаратів для лікування глаукоми на добу (1 крапля), інтервал маси крапель для кра-

Таблиця 1. Перелік первинного пакування готових препаратів тимололу і таурину в формі очних крапель

\begin{tabular}{|c|c|c|}
\hline Назва лп & Виробник & Первинне пакування \\
\hline Тимолол & ПАО «Фармак», Україна & по 5 мл або 10 мл у фрлаконах з поліетилену низької щільності \\
\hline $\begin{array}{l}\text { Тимолол- } \\
\text { Дарница }\end{array}$ & $\begin{array}{l}\text { Фармацевтична фрірма } \\
\text { Дарница, Україна }\end{array}$ & $\begin{array}{l}\text { по } 5 \text { мл або } 10 \text { мл у фрлаконах з полімерного матеріалу, } \\
\text { закритих кришками-крапельницями з контролем розкриття }\end{array}$ \\
\hline Тимолол & $\begin{array}{l}\text { ООО «Стирол- } \\
\text { біофрарм»,Україна }\end{array}$ & по 1мл у фрлаконах з поліетилену низької щільності \\
\hline $\begin{array}{l}\text { Тимолол- } \\
\text { ЛЭНС }\end{array}$ & ООО "ЛЭНС-Фарм", Росія & $\begin{array}{l}\text { по } 5 \text { мл або } 10 \text { мл у скляних фрлаконах в комплекті з кришкою- } \\
\text { крапельницею }\end{array}$ \\
\hline $\begin{array}{l}\text { Офртан } \\
\text { тимолол }\end{array}$ & Сантен АО, Фінляндія & по 5 мл у фрлаконах з поліетилену \\
\hline $\begin{array}{l}\text { Тауфон- } \\
\text { Дарница }\end{array}$ & $\begin{array}{l}\text { Фармацевтична фрірма } \\
\text { Дарница, Україна }\end{array}$ & $\begin{array}{l}\text { по } 5 \text { мл або } 10 \text { мл у фрлаконах з полімерного матеріалу, } \\
\text { закритих кришками-крапельницями з контролем розкриття }\end{array}$ \\
\hline $\begin{array}{l}\text { Tаусрорин } \\
\text { «Оз» }\end{array}$ & $\begin{array}{l}\text { ТОВ «Дослідний завод } \\
\text { «ГНЦЛС», Україна }\end{array}$ & $\begin{array}{l}\text { по } 5 \text { мл в скляних фрлаконах в комплекті з кришкою- } \\
\text { крапельницею }\end{array}$ \\
\hline Тауфрон & ПАО «Фармак», Україна & $\begin{array}{l}\text { по } 5 \text { мл или } 10 \text { мл у фрлаконах з поліетилену низької } \\
\text { щільності }\end{array}$ \\
\hline Тауфрон & ВАТ «Стирол-біофрарм»,Україна & по 1мл у фрлаконах з поліетилену низької щільності \\
\hline $\begin{array}{l}\text { Тауфрон- } \\
\text { ЛЭНС }\end{array}$ & ВАТ "ЛЭНС-Фарм", Росія & $\begin{array}{l}\text { по } 5 \text { мл або } 10 \text { мл у скляних фрлаконах в комплекті з кришкою- } \\
\text { крапельницею }\end{array}$ \\
\hline Тауфрон & $\begin{array}{l}\text { ФГУП "Московский } \\
\text { эндокринный завод" }\end{array}$ & $\begin{array}{l}\text { По 1,5 мл, } 2 \text { мл або } 5 \text { мл в тюбик-крапельницях полімерних, по } \\
5 \text { мл або } 10 \text { мл у фрлаконах-крапельницях полімерних, по } 5 \text { мл в } \\
\text { скляних фрлаконах в комплекті з кришкою-крапельницею }\end{array}$ \\
\hline $\begin{array}{l}\text { Bestoxol Eye } \\
\text { Drops }\end{array}$ & $\begin{array}{l}\text { World Medicine Ophthalmics, } \\
\text { Велікобританія }\end{array}$ & $\begin{array}{l}\text { по } 10 \text { мл у фрлаконах } 3 \text { полімерного матеріалу, закритих } \\
\text { кришками-крапельницями з контролем розкриття }\end{array}$ \\
\hline
\end{tabular}

ISSN 2312-0967. Pharmaceutical review. 2015. № 4 
Фармацевтична технологія, біофармація, гомеопатія Pharmaceutical technology, biopharmacy, homeopathy

пельниць вітчизняного виробництва (25-45 мкг [32]), а також термін зберігання очних крапель після розкриття фрлакону (1 місяць), дослідження заплановані в наступних видах первинного пакування:

1. Флакони номінальною місткістю 5 мл із трубки скляної зі скла медичного марки (водостійкість внутрішньої поверхні класу А), укупорені гумовими пробками, обтиснуті ковпачками алюмінієвими.

2. Пластмасові контейнери місткістю 1 мл, 5 мл 3 поліетилену низької щільності (високого тиску), виготовлені способом Blow-Fill-Seal packaging system.

3. Пластмасові збірні контейнери місткістю 5 мл 3 поліетилену низької щільності.

Закупорювальні засоби (пробки) для скляних фрлаконів виготовлені з гумової суміші на основі бромкаучуку або на основі бромбутилового і хлорбутилового каучуку, вкриті силіконом.

Критерії якості лікарського препарату, відповідні призначеній для розміщення на ринку продукції.

Основні вимоги до якості очних крапель регламентують ДФУ і фрармакопеї світу в загальних фрармакопейних статтях на ЛФ [32-33]. Показники якості очних крапель контролюються при виробництві і протягом терміну зберігання. Критерії прийнятності окремих 3 них наведені у фрармакопеях світу і у НД [32]. Практично всі вони контролюються також при встановленні терміну зберігання препарату після розкриття первинної упаковки і його застосування.

Разом 3 регламентованими при ФР очних крапель необхідно враховувати і такі медико-біологічні вимоги, як:
- відповідність показників більшості препаратів показникам нормального стану слізної рідини $(\mathrm{pH}$, осмоляльність, іонна сила, поверхневий натяг, показник заломлення) [32-33];

- залежно від терапевтичного призначення препарату (наприклад, ССО) відхилення показників препаратів від показників нормального стану слізної рідини (осмоляльність, в'язкість) для більшої ефективності та кращої переносимості препарату.

В переліку медико-біологічних показників контролю підлягають $\mathrm{pH}$, осмолярність (за бажанням виробника) залежно від терапевтичного призначення - в'язкість, осмолярність, показник заломлення, поверхневий натяг.

Узагальнюючий перелік основних вимог до ЛФ очні краплі у вигляді водного розчину в багатодозових контейнерах та критерії прийнятності, які розроблено нами засновуючись на аналізі та оцінюванні даних різних нормативних документів та інсрормаційних джерел, наведено в роботі [33].

В основу аспекту «критерії якості ЛП» для комбінованих очних крапель антиглаукомної дії з тимололу малеатом і таурином був покладений саме цій перелік показників якості для лікарської форми очні краплі.

Таким чином, вищенаведене обґрунтування дозволило визначити цільовий профріль якості для планування розробки комбінованих очних крапель антиглаукомної дії з тимололом малеатом і таурином, що наведений в таблиці 2.

Таблиця 2. Цільовий профіль якості комбінованих очних крапель на основі тимололу малеату і таурину

\begin{tabular}{|c|c|}
\hline Аспекти цільового профрілю якості & Критерії \\
\hline 1 & 2 \\
\hline Передбачуване застосування у клінічних умовах & $\begin{array}{l}\text { Комбінований очний лП антиглаукомної дії, лР якого } \\
\text { впливають на різні ланцюги патогенезу: зниження ВОТ } \\
\text { шляхом зменшення утворення водянистої вологи за рахунок } \\
\text { тимололу малеату та посилення відтоку водянистої вологи } \\
\text { за рахунок таурину, а також вплив на симптоми ССО за } \\
\text { допомогою обраних в процесі дослідження ДР }\end{array}$ \\
\hline Шлях введення & Інстиляція в око \\
\hline Лікарська фрорма & Очні краплі \\
\hline Сили дії дози & $\begin{array}{l}\text { Тимололу малеат в концентрації 0,34\% та таурин в } \\
\text { концентрації } 4 \text { \% }\end{array}$ \\
\hline Система контейнер/закупорювальний засіб & $\begin{array}{l}\text { - фрлакони номінальною місткістю } 5 \text { мл зі скла медичного, } \\
\text { укупорені гумовими пробками та обтиснуті ковпачками } \\
\text { алюмінієвими; } \\
\text { - контейнери місткістю } 1 \text { мл і } 5 \text { мл з поліетилену низької } \\
\text { щільності, виготовлені способом Blow-Fill-Seal packaging } \\
\text { system; } \\
\text { - збірні контейнери місткістю } 5 \text { мл з поліетилену низької } \\
\text { щільності. }\end{array}$ \\
\hline \multicolumn{2}{|l|}{$\begin{array}{l}\text { Критерії якості лікарського препарату, відповідні } \\
\text { призначеній для розміщення на ринку продукції: }\end{array}$} \\
\hline Прозорість & $\begin{array}{l}\text { Практично прозорий (залежно від фрізико-хімічних } \\
\text { властивостей ЛР і ДР) }\end{array}$ \\
\hline
\end{tabular}

ISSN 2312-0967. Фармацевтичний часопис. 2015. № 4 
Фармацевтична технологія, біофармація, гомеопатія Pharmaceutical technology, biopharmacy, homeopathy

Продовження табл. 2

\begin{tabular}{|l|l|}
\hline \multicolumn{1}{|c|}{1} & \multicolumn{1}{|c|}{2} \\
\hline Кольоровість & $\begin{array}{l}\text { Безбарвний (залежно від орізико-хімічних властивостей лР і } \\
\text { ДР) }\end{array}$ \\
\hline$p H$ & Бажана відповідність рН слізної рідини, 7,4 \\
\hline Осмолярність & $280-400$ мосмоль/л \\
\hline Показник заломлення & $1,336-1,357$ \\
\hline В'язкість & Не більше 30 мПа·с \\
\hline Стерильність & Повинен бути стерильним \\
\hline Механічні включення & Повинні бути практично вільними від часток \\
\hline Кількісний вміст лР & $90-110 / 95-105 \%$ \\
\hline $\begin{array}{l}\text { Кількісний вміст антимікробних консервантів, } \\
\text { антиоксидантів та ін. ДР }\end{array}$ & $90-110 \%$ \\
\hline $\begin{array}{l}\text { Об'єм вмісту контейнера (для багатодозових } \\
\text { контейнерів) }\end{array}$ & 1 мл або 5 мл препарату \\
\hline Термін зберігання & 2 роки \\
\hline Термін зберігання після відкриття контейнера & Не має перевищувати чотирьох тижнів \\
\hline
\end{tabular}

Висновки. Застосування наукових підходів до аналізу і оцінки матеріалів різних інформаційних джерел щодо комбінованої терапії глаукоми препаратами 3 лікарськими речовинами різноспрямованої дії та наявних наукових знань щодо лікарської фрорми очні краплі дозволило спланувати цільовий профріль якості для розробки комбінованих очних крапель для терапії глаукоми.

В якості діючих речовин для комбінованого лікарського препарату антиглаукомної дії обґрунтований вибір тимололу малеату, що знижує утворення водянистої вологи, та таурину, який забезпечує збільшення відтоку водянистої вологи.

Обґрунтовано доцільність включення в лікарський препарат речовин, які впливають на стабільність слізної плівки та проявляють захисну і репаративну дію на клітини рогівки та кон'юнктиви i, таким чином, запобігають появі побічних ефектів від постійного використання гіпотензивних очних крапель.

\section{Список літератури}

1. Лікарські засоби. Фармацевтична розробка (ICH Q8): СТ-H МО3У 42-3.0:2011. - Частина II: Додаток до керівних вказівок з фрармацевтичної розробки (ICH Торіс Q 8 Додаток до фрармацевтичної розробки) - К. : МO3 України, 2011. - 33 с. - (Настанова).

2. Державний реєстр лікарських засобів України. [Електроний ресурс]. - Режим доступу: - http://www.drlz. kiev.ua/

3. Компендиум on-line. - [Електроний ресурс]. - Режим доступу: -http://compendium.com.ua/

4. Регистр лекарственных средств России ${ }^{\circledR}$. РЛС ${ }^{\circledR}$. [Електроний ресурс]. - Режим доступу: - http://www. rlsnet.ru/

5. Справочник Видаль «Лекарственные препараты в России». - [Електроний ресурс]. - Режим доступу: http://www.vidal.ru/

6. Рациональная фармакотерапия в офтальмологии: рук. для практикующих врачей / Е. А. Егоров, В. Н. Алексеев, Ю. С. Астахов, В. В. Бржевский, А. Ф. Бровкина и др.; под общ. ред. Е. А. Егорова. - М. : Литтерра, 2004. - 954 с. 7. Куроедов А. В. Перспективы применения комбинированных атиглаукомных препаратов (обзор литературы) / А.В. Куроедов // Клиническая офртальмология. - 2007. - № 4. - С. 176 -180.

8. Куроедов А. В. Агрессия против прогрессии: как мы понимаем эффеектиность комбинированных антиглаукомных препаратов (обзор литературы) / А. В. Куроедов // Клиническая офтальмология. - 2008. - №4. - С. 143 -145.

9. Астахов Ю. С. Общие принципы медикаментозного лечения заболеваний глаз / Ю. С. Астахов, Е. А. Егоров, Т. В. Ставицкая // Клиническая офтальмология. - 2004. - № 1. - C. 2-5.

10. Егоров Е. А. Отдельные клинико-эпидемиологические характеристики глаукомы в странах СНГ и Грузии. Результаты многоцентрового открытого ретроспективного исследования (часть 2) / Е. А. Егоров, А. В. Куроедов // Клиническая офтальмология. - 2012. -№ 1. - C. 19-22.

11. Lombardini J. B. Effects of taurine and mitochondrial metabolic inhibitors on ATP-dependent $\mathrm{Ca} 2+$ uptake in synaptosomal and mitochondrial subcelluar fractions of rat retina / J. B. Lombardini // Neurochem. - 1988. - Vol. 51, №1. - P. 200-205.

12. Duffin R. M. Suppresion of adrenergic adaptation in the eye with prostaglandin synthesis inhibitor/ R. M. Duffin, R. E. Christensen, M. V. Bcrgamini //Invest. Ophthal. Vis Sci. - 1980. - Vol. 21, №5. - P. 756-759.

ISSN 2312-0967. Pharmaceutical review. 2015. № 4 
Фармацевтична технологія, біофармація, гомеопатія Pharmaceutical technology, biopharmacy, homeopathy

13. Майчук Ю. Ф. Таусрон в лечении глазных болезней. Обзор литературы и собственные наблюдения // Медицинские технологии. Оценка и выбор. -2011. -N 1. -С.56-61.

14. Нефёдов Л. И. Таурин (биохимия, фрармакология и медицинское применение). -Гродно , 1999. -145с.

15. Бунин А. Я. Результаты сочетанного применения тауфона и тимолола при лечении больных открытоугольной глаукомы / А. Я. Бунин, В. Н. Ермакова, М. А. Бабижаев. // Вестн. офтальмологии. - 1990. T. 106, №4. - C .9-11.

16. Ермакова В. Н. Эфрфективность сочетания Тауфона с антиадренергическими препаратами при первичной открытоугольной глаукоме/ В. Н. Ермакова // Российский офтальмологический журнал. - 2008. - № 2. - С. 12-17. 17. Olah J. Rabbit's intraocular pressure after instillation of timolol and aminoacid lysine, arginine, glycine or taurine mixture / Z. Olah, J. Veselovsky // Bratisl Lek Listy. - 2007. - Vol. 108, №7. - P. 283-286.

18. Пат. $79245 \cup$ Україна. А61K9/08; A61P27/02; А61К31/00. Лікувальний гель для очей «Таугель» / Соколова Л.В. (UA), Бердей I.I. (UA). -№ u 201213798; заявл. 03.12.2012; опубл. 10.04.2003, Бюл. № 7.

19. Bestoxol (Eye Drops), World Medicine Ophthalmics -[Електроний ресурс]. - Режим доступу: -http://www. wm-ophthalmics.com/bestoxol_eye_drops.asp

20. Taurine Eye Drops, Hangzhou East Pharmaceutical Co., Ltd. - [Електроний ресурс]. - Режим доступу: -http://www.ectrade.com/Auction/FreeSample/361379431/ Qingru_Taurine_Eye_Drops.html

21. Taurine Eye Drops, Hubei Kangzheng Pharmaceutical Co., Ltd. [Електроний ресурс]. -Режим доступу: -http:// image.made-in-china.com/2f0j00lvwQiVOhMSpF/TaurineEye-Drops.jpg

22. Taurine Eye Drops $0,4 \mathrm{~g} / 8 \mathrm{ml}$, AdvaCarePharma -[Електроний ресурс]. - Режим доступу: -http:// www.advacarepharma.com/en/pharmaceuticals/otherpreparations/item/441-taurine-eye-drops.html

23. Ушакова Л. И. Возникновение и развитие синдрома «сухого глаза» у больных первичной открытоугольной глаукомой / Л. И. Ушакова, О. Н. Шункевич // Глаукома: теории, тенденции, технологии. HRT/Spectralis Клуб Россия -2013: материалы XI Международного конгресса.- М., 2013. - С. 260-264.

24. Basal Tear Turnover and Topical Timolol in Glaucoma Patients and Healthy Controls by Fluorophotometry I
Esmeralda V. M. J. Kuppens, Thorsren R. Srolwijk, Rob J. W. de Keizer [et. al] // Investigative Ophthalmology \& Visual Science. - 1992. - Vol. 33, No. 12. - P. 3442 3448.

25. Podder S.K. Improving the safety of topically applied timolol in the pigmented rabbit through manipulation of formulation composition / S. K. Podder, V. C. Moy, V. H. L. Lee // Exp. Eye Res. - 1992. - Vol. 54, №5. P. 747-757.

26. Bioadhesion: The effect of polyacrylic acid on the ocular bioavailability of timolol / F. Thermes, A. Rozier, B. Plazonnet [et al.] // Int. J. Pharm. - 1992. -Vol.81. - P. 59-65.

27. The effect of vehicle viscosity on the ocular bioavailability of L-653,328 / J. Grove , M. Durr , M.P. Quint [et al.] // Int. J. Pharm. - 1990. - Vol. 66, № 1-3. - P. 23-28.

28. Пат. 8501822 США. А61К31/7028; A61P27/02; A61P29/00. Ophthalmic composition containing alginic acid or salt thereof / Matsumoto Eri, Nishina Yasuko, Haruna Kenichi, Arita Harumasa, Kita Akiko, (JP). -№13/431,002; заявл. 27.03.2012; опубл. 6.08.2013. -18 p.

29. Different Effects of Absorption Promoters on Corneal and Conjunctival Penetration of Ophthalmic Beta-Blockers I H. Sasaki [et al.] // Pharmaceutical Research. - 1995. - Vol. 2, №8. - P. 1146-1150.

30. Заява 20100311688 США. А61К31/717; A61P27/04. Ophthalmic formulations, methods of manufacture, and methods of using same / Chapin; Matthew J., Minno George, Nice Jackie, Ousler III George W., Abelson Mark B. (USA). -№12/794315; заявл. 4.06.2010; опубл. 9.12.2010. $-30 \mathrm{p}$.

31. Пат. 8450295 США. A61K 31/723; A61K 31/198; A61K 31/145. Ophthalmic composition containing xanthan gum and amino acid / Doi Koji, Aki Hiroshi (JP). -№12/767,185; заявл. 26.04.2010; опубл. 28.05.2013. -10 р.

32. Андрюкова Л.М. Дослідження 3 стандартизації фрармацевтичної розробки лікарськихпрепаратів у формі очних крапель: автореф. дис. на здобуття наук. ступеня докт. фрармац. наук : спец. 15.00.03 «Стандартизація та організація виробництва лікарських засобів» / Л. М. Андрюкова. -Харків, 2011. -38 с.

33. Андрюкова Л.М. Визначення критичних показників якості лікарської фрорми очні краплі / Л. М. Андрюкова, О. Г. Фетісова, О. М. Якубчук, С. М. Коваленко // Управління, економіка та забезпечення якості в фрармації. -2013. -№ 6. -С. 4-9.

\title{
ОБОСНОВАНИЕ ЦЕЛЕВОГО ПРОФИЛЯ КАЧЕСТВА ДЛЯ РАЗРАБОТКИ КОМБИНИРОВАННЫХ ГЛАЗНЫХ КАПЕЛЬ ДЛЯ ТЕРАПИИ ГЛАУКОМЫ
}

\author{
А. Н. Якубчук, Е. Г. Фетисова, А. В. Доровской, Л. Н. Андрюкова
}

Национальный фрармацевтический университет, Харков

Резюме: в статье приведено обоснование для всех составляющих целевого профиля качества, который положен в основу планирования разработки комбинированных глазных капель антиглаукомного действия. Обоснование ожидаемого набора показателей качества ЛП, который в идеале будет достигнут для выполнения предназначенной фрункции, проведено сприменением какнаучныхподходов кобзору и оценке материалов различныхинформационных источников по вопросу комбинированной терапии глаукомы препаратами разнонаправленного действия, так и имеющихся научных знаний о лекарственной форме глазные капли.

ISSN 2312-0967. Фармацевтичний часопис. 2015. № 4 
Фармацевтична технологія, біофармація, гомеопатія

Pharmaceutical technology, biopharmacy, homeopathy

Ключевые слова: комбинированные глазные капли, глаукома, целевой профиль качества, показатели качества.

\section{SUBSTANTIATION OF A QUALITY TARGET PROFILE FOR THE DEVELOPMENT OF COMBINED EYE DROPS FOR GLAUCOMA TREATMENT}

\section{Yakubchuk, O. H. Fetisova, A. V. Dorovskyi, L. M. Andryukova}

National University of Pharmacy, Kharkiv

Summary: the article presents a substantiation for all constituents of a quality target profile, that forms the basis of development planning of the combined eye drops for therapy of glaucoma. The substantiation of the expected set of the preparation quality indexes, that in an ideal will be achieved for performing the intended purpose, has been carried out with the use of the scientific approach to review and estimation of materials from different informative sources concerning question of the glaucoma combined therapy by the differently directed action preparations so as present scientific knowledge about the eye drops medicinal form.

Key words: combined eye drops, glaucoma, quality target profile, quality indexes.

Отримано 09.09.2015 p.

ISSN 2312-0967. Pharmaceutical review. 2015. № 4 